\title{
Fábulas e fronteiras na poética urbana de Francis Alÿs
}

\section{Fables and frontiers in Francis Alÿs' urban poetic}

Germana Konrath ${ }^{1}$ 


\section{Resumo}

Com uma trajetória poética entrelaçada pela ideia de fábula, Francis Alÿs desenvolve ações que praticamente não deixam rastros materiais. Seus trabalhos partem de situações cotidianas onde o artista insere novas narrativas, possibilitando percepções e perspectivas inaugurais sobre determinados contextos. Este artigo busca estabelecer relações entre as fábulas criadas por Alÿs e suas contribuições para nossos discursos e práticas em situações limítrofes ou marginais, tanto entre territórios quanto entre fazeres urbanos diários.

Palavras-chave: Fábulas urbanas; Francis Alÿs; fronteiras; espaços comuns; arte contemporânea.

\section{Abstract}

With a poetic trajectory intertwined with the idea of fable, Francis Alÿs develops actions that leave practically no material traces. His works have as starting point daily situations where the artist inserts new narratives, enabling perceptions and inaugural perspectives on certain contexts. This article seeks to establish relationships between the fables created by Alÿs and their contributions to our discourses and practices in borderline or marginal situations, both between territories and between daily urban practices.

Keywords: Urban fables; Francis Alÿs; frontiers; common spaces; contemporary art. 


\section{PONTO DE PARTIDA}

O texto que aqui se introduz trata do potencial político que trabalhos desenvolvidos pelo artista belga-mexicano, Francis Alÿs, apresentam em relação à nossa forma de pensar e de ocupar espaços comuns, incluindo margens e fronteiras. A investigação aborda, especificamente, as possibilidades de intervenção na memória, na percepção e nas perspectivas construídas acerca de nossas cidades e de seus espaços públicos por meio das fábulas urbanas criadas por Alÿs em sua trajetória. Partimos de um panorama inicial, contextualizando sua produção artística para, a seguir, nos determos em duas ações poéticas realizadas por Alÿs, colaboradores e voluntários, no mar do Caribe, em 2006, e no estreito de Gibraltar, em 2008.

A análise da produção de Alÿs e de seu posicionamento frente e ela, bem como frente às fronteiras impostas, se torna ainda mais relevante em momentos de embotamento de experiências estéticas e de brutalização das sensibilidades, como este que vivemos. A "burocratização do amanhã" toma lugar na urbe contemporânea, ocupando seus tempos e espaços e se faz presente nos discursos e práticas hegemônicos que modelam nossas agendas e fazeres diários, tornando-os programáticos e limitados. A partir de uma trajetória poética que opera pelo avesso da ideia de produtividade, Alÿs nos aponta maneiras de fugir dessa linearidade dos discursos dominantes. $O$ artista sugere novas possibilidades de compartilhamento e de participação política através de suas intervenções que tão pouco geram em termos de resultados físicos, materiais. Seus trabalhos aproximam-se, segundo o próprio Alÿs, do conceito de fábulas, permitindo distintas interpretações, registros e modos de circulação. $O$ estudo visa analisar a forma como essas práticas podem desconstruir a esteira dos clichês que preenche nossas rotinas e espaços comuns.

A fundamentação teórica que dará sustento à discussão parte de alguns conceitos-chave como: tática e estratégia, de Michel de Certeau; agenciamento territorial, de Gilles Deleuze e Félix Guattari; e a relação entre estética e política, postulada por Jacques Rancière. $O$ estudo é baseado, ainda, em um entendimento sobre espaço público - ou espaço comum - baseado no legado de Certeau acerca do termo espacialização e de Rancière a respeito da pólis e de seus espaços de partilha.

Se é verdade, afinal, que a cidade sintetiza em um único e complexo símbolo toda a produção humana, como afirma o escritor Italo Calvino ${ }^{1}$, então o espaço público torna-se a expressão máxima dessa produção, reunindo e concentrando experiências políticas, culturais e socioeconômicas da humanidade desde que se tem registro. $O$ espaço público revela-se como a essência da urbe, seu núcleo fundamental. Se formos um pouco além, entenderemos que esse espaço é também o elemento central do que é político, cuja raiz etimológica é pólis. Rancière atenta justamente para essa distinção, ao se referir ao político e não à política, no sentido de "tratar de princípios da lei, do poder e da comunidade e não da cozinha governamental." (RANCIĖRE, 1998 apud LAGNADO; PEDROSA, 2006, p. 54).

Segundo o filósofo francês, a política designaria uma atividade, enquanto o po-

1 Italo Calvino, ao comentar seu apreço pela obra As Cidades Invisíveis, afirma que se o livro "continua sendo para mim aquele em que penso haver dito mais coisas, será talvez porque tenha conseguido concentrar em um único símbolo todas as minhas reflexões, experiências e conjecturas, [...] em que a cidade deixa de ser um conceito geográfico para se tornar símbolo complexo e inesgotável da existência humana." (2003, contracapa). 
lítico teria como objeto a instância da vida comum. Mesmo quando aqui se fala em política, no feminino, é a esta instância da vida comum que o artigo se refere, mais especificamente ao espaço onde, por excelência, essas relações cotidianas se projetam: o espaço público. Aqui o espaço público é entendido como local das práticas diárias da cidade, da partilha do comum. Ou seja, o artigo está alinhado à definição de Certeau, para quem "o espaço é um lugar praticado. Assim a rua geometricamente definida por um urbanismo é transformada em espaço pelos pedestres." (1994, p. 202).

A figura urbana da rua, mencionada por Certeau, pode ser emblemática ao falarmos de espaços comuns na contemporaneidade, pois talvez seja hoje a representação mais direta do espaço comum. Não à toa, muitos dos trabalhos de Alÿs têm a rua como espaço de ação. Ela toma atualmente o lugar que a piazza ocupou historicamente na vida urbana ocidental. Ao mesmo tempo em que temos uma tendência à desurbanização das cidades, ao esvaziamento das funções políticas dos espaços públicos constituídos, a rua ganha importância e se torna símbolo da participação dos cidadãos, de forma não coreografada ou controlada pelo sistema. O chamado para "sair às ruas" é entendido nos dias atuais como um convite à política, à partilha do sensível como diria Rancière, onde novas formas sociais são inventadas ou transformadas, tornando esse espaço o palco preferencial de ações artísticas, celebrações, manifestações, disputas e conflitos que ocorrem na cidade e em suas margens.

Quando começa sua carreira artística, Alÿs parte de pequenas intervenções, inicialmente em janelas de prédios, depois na rua, na praça central da cidade, até chegar ao limite do urbano e, finalmente, na fronteira entre terra e mar. Alÿs está, aparentemente, ampliando seus territórios de atuação. Não se trata de uma evolução, nem sequer de um movimento linear para fora ou de um processo único e unidirecional. Alÿs segue reterritorializando, retornando e produzindo trabalhos mais "circunscritos" ao espaço urbano ao longo de toda sua carreira. Mais do que abranger territórios geográficos que vão cada vez mais em direção à periferia, esse movimento suscita perguntas quanto aos limites conceituais que delimitam o que é a cidade, o espaço público e quais são as possibilidades da arte intervir, através de experiências estéticas, na partilha do comum.

Acompanhando o artista nesse movimento passamos a perceber o espaço público urbano não mais como a rua, a calçada, a praça constituída no centro da cidade: alargamos nossa concepção para abarcar o perímetro da megalópole, com suas bordas indefinidas. Lançamo-nos rumo ao entendimento das dunas de areia, das praias, das águas como espaços comuns. A cidade torna-se esse espaço-tempo onde a sociedade se projeta, tanto física como simbolicamente. A cidade, enfim, não é feita das coisas, outrossim das relações e dos espaços-tempos entre as coisas e entre as próprias cidades.

Ao perceber essa trama, Alÿs propõe ações que intervenham não na materialidade das cidades - como operações de soma - mas sim nas narrativas construídas a seu respeito. Assim, a ficção toma um papel fundamental na trajetória do artista e a criação de suas fábulas surge como uma possibilidade de transformação urbana sob diferentes formas, por meio de distintas táticas de inserção e aplicação. Para Alÿs, a ficção não ocupa um espaço menor nem subordinado à realidade - ao contrário, a realidade está necessariamente moldada por nossa imaginação e por nossa memó- 
ria. Dessa maneira o futuro pode ser alterado se interviermos no passado, mas não nos fatos passados, através de uma possível máquina do tempo, e sim nas narrativas sobre o passado, transformando-as. Uma fábula inserida na memória da cidade seria capaz de alterar, no presente, o modus operandi e a visão de seus habitantes a seu respeito. É o que parece defender Alÿs com seus projetos, questionando conceitos fechados e aparentes consensos sobre determinadas situações.

\title{
2. FONTES
}

Em O que é a filosofia?, Deleuze e Guattari enunciam que não devemos simplesmente acreditar em visões sedentárias, pois cada conceito tem um percurso, uma história apoiada em outras anteriores que deve ser sempre recontextualizada. Cada conceito seria um ponto de condensação teórica, um centro de vibrações ao mesmo tempo dentro de si próprio e também em relação aos demais que o circundam. Daqui já é possível antever porque a ideia de agenciamento ou, mais precisamente, de agenciar, é tão cara a Deleuze e Guattari, que operam esse verbo para elucidar o que lhes interessa no mundo, e qual sua perspectiva de entendimento do próprio conhecimento.

\begin{abstract}
A unidade real mínima não é a palavra, nem a ideia ou o conceito, nem o significante, mas o agenciamento. É sempre um agenciamento que produz os enunciados. [...] O enunciado é o produto de um agenciamento, sempre coletivo, que põe em jogo, em nós e fora de nós, populações, multiplicidades, territórios, devires, afetos, acontecimentos. [...] O agenciamento é o cofuncionamento, é a "simpatia", a simbiose. (DELEUZE; PARNET, 1998, p. 43).
\end{abstract}

Os agenciamentos seriam ações operando constantemente entre agentes (e não sujeitos), a partir de trocas e transformações, de movimentos tanto físicos - em que o agenciamento se daria num nível entre corpos, uns operando sobre os outros quanto conceituais, nos quais o agenciamento seria coletivo, de enunciação. Assim, quando falam de agenciamento territorial, Deleuze e Guattari declinam do uso da palavra território para falarem sempre de territorialização, desterritorialização e reterritorialização. Seriam três ações necessariamente engendradas, visto que, para os autores, não há movimento de territorialização sem que, simultaneamente, haja uma desterritorialização daquele espaço-tempo antes ocupado e também uma reterritorialização do mesmo por outros agentes.

Vale ressaltar que, mesmo no caso de processos "revertidos", de retornos, nunca voltamos ao mesmo, ao anterior. Nunca o território será o de antes nem nós seremos os mesmos. A relevância de uma ação - de um agenciamento territorial - mesmo que efêmera, não ocorre apenas durante sua execução, nem deve ser considerada infrutífera no caso de um aparente retorno à situação anterior, visto que os agentes se transformam no processo assim como o próprio desejo ou a coisa na qual se transforma. É um entendimento que parte da ideia de que cada agente está em processo ininterrupto de transformação e produção de si nos devires.

O agenciamento territorial seria, por conseguinte, uma condensação, um acúmulo de espaço-tempo onde agentes se sucedem, onde o território deixa de ser coi- 
sa para se tornar ato. Segundo os filósofos, essa territorialização se dá através de ritmos, de atos expressivos, que tornam o meio ou o ambiente em questão qualitativo, atribuindo-lhe novas características. Como diriam os pensadores, "o território seria o efeito da arte. Não no sentido que essas qualidades pertenceriam a um sujeito, mas no sentido que elas desenham um território que pertencerá ao sujeito que as traz consigo ou que as produz." (DELEUZE; GUATTARI, 1998, p. 123).

A ideia de migrações (de pessoas, de capital e de significados) pode soar como natural nos dias de hoje, em tempos de extrema desterritorialização. Mas aqui entra novamente a postura crítica que nos interessa, como nas ações em que Alÿs nos confronta com barreiras tão invisíveis quanto reais, questionando clichês contemporâneos de fluxo e de globalização. Podemos lançar as seguintes perguntas a partir dos trabalhos de Alÿs: quais são as contribuições de ações efêmeras para a desconstrução de barreiras históricas? Existe um real atravessamento de fronteiras em sua produção?

Outro autor chamado para atravessar a produção de Alÿs e que trabalha com a ideia de espaço (urbano) e de fronteiras é Michel de Certeau. Certeau trabalha a partir da percepção de que haveria uma lacuna teórica nas ciências sociais em relação à forma como as pessoas comuns, não artistas ou não criadoras necessariamente, se reapropriam daquilo que lhes é oferecido pelo sistema dominante, seja a linguagem, as tradições, os signos e símbolos, os objetos, o planejamento urbano ou as cidades. Segundo ele, as maneiras de adaptar - de forma individual, heterogênea e subjetiva ou subconsciente - o que, a princípio, deveríamos apenas consumir, seriam ações subversivas, que o autor chama de táticas. As táticas engendram outras maneiras de articular nossas práticas cotidianas, gerando microrresistências àquilo que as instituições e as normas representam. Nesse processo, Certeau diferencia ações táticas de ações estratégicas - e aqui parece importante frisar que a diferença reside muito antes na metodologia do que no produto resultante de cada um desses processos.

O filósofo nos indica que as táticas seriam um modo não passivo de lidar com o sistema dominante, "artes de fazer" não formais, desempenhadas por cada um de nós, as quais se oporiam às estratégias utilizadas pelo sistema hegemônico. Estratégia, por outro lado, seria uma entidade dominante ou de autoridade reconhecida, uma instituição estabelecida em conformidade com o sistema e a ordem instituída. Como exemplos, podemos citar o Estado, as leis, a gramática, a economia formal, os produtos comerciais, a propaganda e a mídia e o planejamento urbano. Essa característica da estratégia, de sempre partir de esquemas a priori, a impediria de adaptar-se ou reestruturar-se com agilidade frente às realidades insurgentes.

Em contrapartida, a tática seria caracterizada pela facilidade de reestruturação, sendo móvel, não institucionalizada. A tática não existe antes, ela surge com e a partir de alguma necessidade. Ela não conhece uma estrutura e se forma no momento da demanda, a partir de práticas específicas. Operações táticas seriam a maneira pela qual assumimos um papel ativo, mesmo que anônimo ou sutil, de subverter ou esquivar do sistema dominante, fundando espaços, tornando-os habitáveis para nós (metafórica e literalmente).

Se, por um lado, o planejamento urbano é a linguagem do poder - disciplinadora, pretensamente onipresente e panóptica -, a cidade e seus habitantes não ces- 
sam de gerar movimentos de contrafluxo, burlando o sistema, trabalhando em seus interstícios de forma quase invisível, escapando à possibilidade de serem governados ou mapeados. Esta, aliás, seria uma de suas forças: a capacidade de se manter invisível para o sistema. Nas palavras de Certeau,

[...] essas práticas do espaço remetem a uma forma específica de 'operações' ('maneiras de fazer') a 'uma outra espacialidade' (uma experiência 'antropológica, poética e mítica do espaço) e a uma mobilidade opaca e cega da cidade habitada. Uma cidade transumante, ou metafórica, insinua-se assim no texto claro da cidade planejada e visível. (1994, p. 172).

O autor não pretende com isso dizer que as táticas se sobrepõem às estratégias ou que são imunes a elas. As táticas não têm recursos próprios e se aproveitam de furos no sistema, operando a partir de pequenas fissuras e criando outras, de forma improvisada. Assim, o comércio informal toma conta das ruas, os atalhos surgem criando caminhos onde vias não foram previstas, restos urbanos são preenchidos, andarilhos e nômades desconstroem a ideia de limites territoriais e de habitat fixo. Contra o sistema que busca chegar a mínimos denominadores comuns, equacionando as necessidades individuais para oferecer um meio termo que homogeneíza a todos, a tática abre caminhos, criando pequenos espaços de liberdade em meio à violência da ordem social imposta. Neste sentido, interessa confrontar os trabalhos de Alÿs para entender como eles produzem movimentos táticos, de que forma criam outras reflexões e maneiras de ocupar a cidade com seus espaços-tempos comuns.

Quando falamos em comum, vale resgatar o legado de Jacques Rancière sobre o termo, sobre aquilo que é partilhado e também sua visão acerca de política. $O$ filósofo defende a existência de duas chaves de entendimento político: a primeira como uma construção pelo acordo e a segunda como um desenvolvimento baseado em dissensos. Rancière coloca em xeque a noção de política enquanto consenso e de que partimos todos de uma sensibilidade comum. Segundo ele "a estética e a politica articulam-se ao dar visibilidade ao escondido, reconfigurando a divisão do sensível e tornando o dissenso evidente." (2009, p. 22).

O filósofo abre a discussão sobre dissenso indicando que não se trata apenas da falta de objetivos ou de afinidades compartilhados, mas sim de um passo anterior, em que os próprios dados da situação, os sujeitos envolvidos, as formas de inclusão ou exclusão, o que é sensível a uma situação, afinal, é passível de desacordo. Ao cunhar o termo partilha do sensível, o autor nos coloca frente à seguinte questão: o que é comum e o que é partilhado, no sentido de exclusão das experiências estéticas de uma comunidade? Quem é excluído pelo sistema (por não dispor de tempo, por não estar no espaço em questão ou por não ter as ferramentas ou sequer a linguagem requerida)?

No caso das ações poéticas de Alÿs, podemos questionar se elas são capazes de criar contornos que permitam aumentar a área de contato e nos aproximar de situações políticas de inclusão ou exclusão invisíveis, porém presentes, em nosso cotidiano. Para Rancière (2009, p. 16), a arguição de Platão é um exemplo desses processos de exclusão do comum. Platão defendia que os artesãos não podiam tomar parte na ágora porque sua dedicação deveria se voltar integralmente ao trabalho, não lhes restando tempo para qualquer outra atividade. Para Aristóteles, em paralelo, todo animal falante seria político, mas tal visão não incluía escravos, pois eles não domi- 
navam a linguagem, por mais que pudessem falar. No processo de urbanização das cidades industriais, os trabalhadores foram relegados aos subúrbios, sem a chance de participar da coisa urbana; já na história das grandes colonizações, as populações nativas da América e da África foram consideradas primitivas e escravizadas por não serem dotadas das capacidades necessárias para ter acesso à vida pública.

Esse jogo pode se dar no tempo e no espaço, impossibilitando a presença de alguns por estarem alhures - como nos subúrbios e periferias; por não disporem do tempo necessário - como nas sociedades contemporâneas com seu modelo de trabalho que preenche os dias com atividades "produtivas" a serem cumpridas; ou ainda, por não disporem das ferramentas e habilidades requeridas para sua participação - caso das populações consideradas primitivas ou subdesenvolvidas. Seja por uma ou outra razão, nos vemos distanciados de determinadas experiências estéticas e políticas.

Para Rancière, a arte poderia reconfigurar essa distribuição geral de atividades através de suas próprias maneiras de fazer ou, como diria Certeau, artes de fazer. Experiências estéticas seriam capazes de transformar ações e pensamentos - ou pensabilidades, como Rancière denomina. $O$ autor indica que é nesse nível da vida comum das pessoas, do recorte sensível do comum, de suas formas de visibilidade e de sua distribuição, que a questão estética/política se impõe. Sugere ainda que atos estéticos podem servir para provocar e induzir novas experiências de subjetividade política.

A estética, portanto, permearia todo processo político e a arte seria o campo mais afeito a esta exploração de outros possíveis, da criação de contornos para aquilo que até então é inominável para o inteligível e para o racional, sendo uma antecipadora do que pode vir a ser e daquilo que a sensibilidade já percebe. Rancière encara como desastrosa a falta de reconhecimento do não saber na ciência, que busca sempre enquadrar em seus padrões de racionalidade quaisquer manifestações. Por isso, é essencial entendermos o quanto o regime estético das artes, ao possibilitar a criação de novas pensabilidades, está indo em direção ao reconhecimento do que já existe no mundo, não como pensamento, mas como experiência. Rancière defende, acerca das práticas estéticas, que se trata de um "sistema das formas que a priori determinam o que se vai experimentar." (RANCIĖRE, 2007 apud CANCLINI, 2012, p. 135). E se a experiência é anterior ao pensamento, então a política, por conseguinte, também deverá ser baseada nessa experiência. Ficam as seguintes perguntas para confrontar a poética de Alÿs: de que maneira seus trabalhos expõem dissensos ou suspendem acordos? E que operações políticas se tornam mais suscetíveis a mudanças a partir das intervenções poéticas desenvolvidas pelo artista?

\section{AÇÕES POÉTICAS E REAÇÕES TEÓRICAS}

Francis Alÿs nasceu na Antuérpia, em 1959, sob o nome Francis De Smedt. Belga, formou-se arquiteto naquele país e, na primeira metade dos anos 1980, mudou-se para Veneza a fim de desenvolver seu doutorado em Urbanismo. Durante sua vivência na Itália, se deparou com a cidade de Palmanova, conhecida por seu desenho em formato de estrela típico de povoados militares fortificados. Ao estudar a cidade e pensar sobre possíveis intervenções no local, absolutamente isolado, cristalizado e desolador, Alÿs teve uma epifania: naquela cidade nenhum material deveria ser adi- 
cionado, fosse pela arquitetura, pela arte ou pelo urbanismo. A apatia de seus habitantes nem a percepção externa sobre Palmanova seria verdadeiramente alterada por intervenções de soma, principalmente no presente. O que poderia ser transformador seria uma intervenção no passado ou, mais precisamente, na história da cidade. Assim Alÿs criou uma fábula a ser enxertada na memória do lugar.

Dez anos mais tarde, em 1995, já tendo firmado residência na Cidade do México, o artista criou o seguinte subtítulo para um de seus projetos, chamado Fairy Tales: "ao passo que as sociedades altamente racionais da Renascença sentiram a necessidade de criar utopias, nós de nossos tempos devemos criar fábulas". Nesse projeto, Alÿs caminhou pela capital mexicana fazendo seu blusão se desfiar, de tal forma que em seu percurso deixou um rastro atrás de si, formado por um fio de lã, enquanto sua roupa se desfazia. Criou assim uma fábula, aproximando-se de outras histórias sobre processos de reconhecimento e de perda (ou possibilidade de regresso), como o conto dos irmãos Grimm João e Maria ou o mito grego sobre o fio de Ariadne e o labirinto do Minotauro.

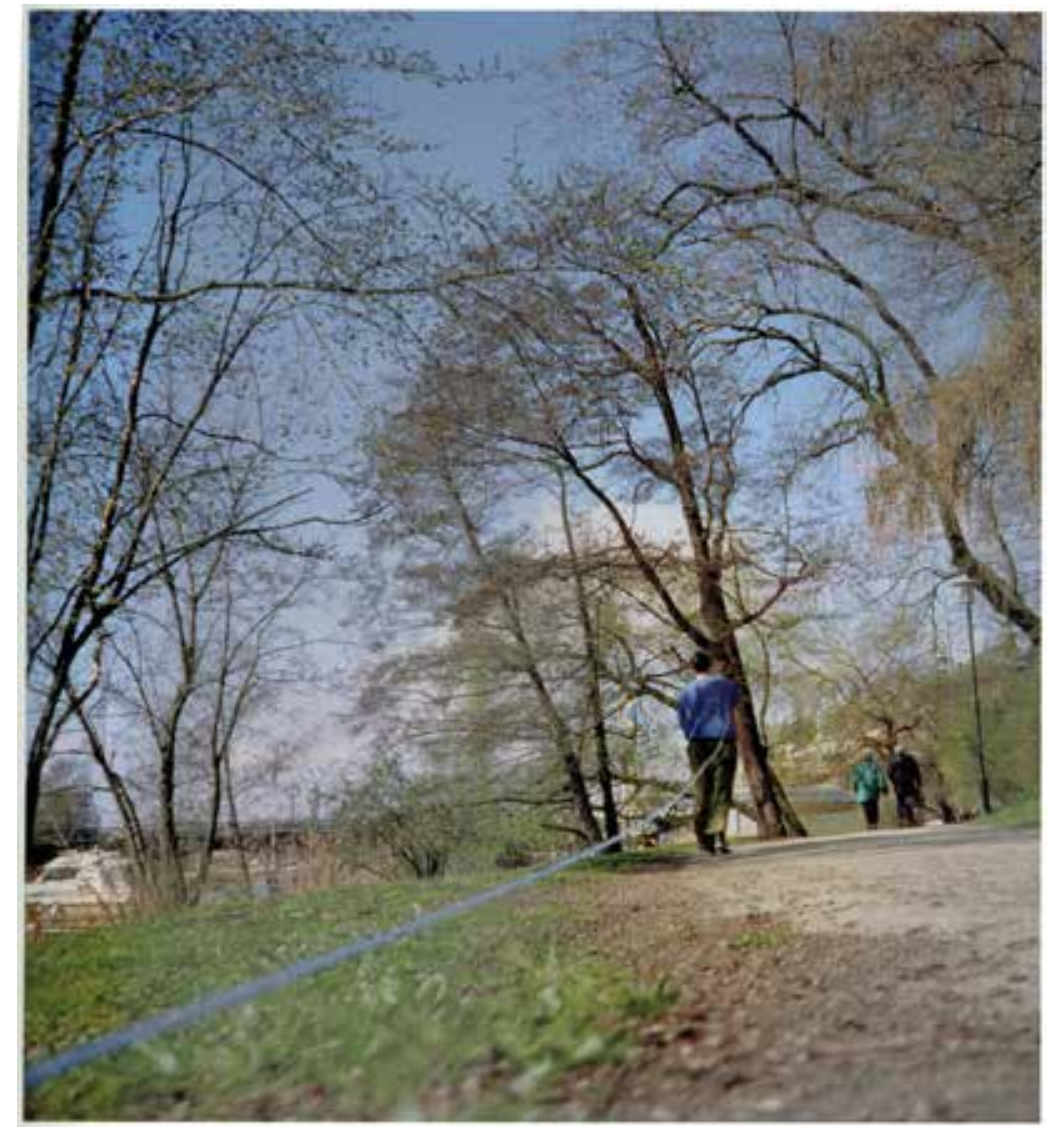

Francis Alÿs. Fairy Tales, 1995-98. Documentação fotográfica de uma ação. Fonte: FERGUSON; FISHER; MEDINA, 2007, p. 27

Francis Alÿs, naquele momento, completava quase uma década no México, para onde mudou-se em 1986 - incialmente fugindo do serviço militar belga e depois por se sentir atraído pela nova vida que aquele caótico país lhe acenava. Trocou o nome Francis De Smedt por Francis Alÿs, de arquiteto passou a artista e, na medida de suas possibilidades, tornou-se cada vez mais latino-americano e menos europeu. A vida, porém, não é assim tão binária e os processo de mudança ali iniciados marcam a produção de Alÿs até hoje. 
A trajetória do artista partiu deste terreno movediço de fronteiras, marcado por deslocamentos físicos, profissionais e identitários que passaram a pautar não apenas uma temática, mas um modus operandi poético. Alÿs declara que, principalmente nos primeiros anos de sua vivência mexicana, seus trabalhos foram uma reação à desmesurada Cidade do México, à sua necessidade de identificação naquele novo contexto, à postura de quem habita as margens entre o local e o estrangeiro, entre o turista e o trabalhador e entre observar e intervir. Desde então, é nesse espaço entre que Alÿs desenvolve seus projetos, questionando limites e esgarçando fronteiras. $O$ artista diz que suas operações ocorrem neste meio onde não há início ou fim, e desafia delimitações aparentemente consensuais, desestabilizando noções lineares de evolução e de progresso.

Desse primeiro momento, podemos destacar alguns trabalhos como The Collector, desenvolvido entre 1990-92, na Cidade do México e atualizado na versão Zapatos magnéticos, realizada em Havana no ano de 1994. Neles, Alÿs criou objetos imantados para coletar, ao longo de suas deambulações pedestres, resíduos metálicos por meio de forças magnéticas. A coleção de troféus colecionados aleatoriamente deixava, atrás de si, um rastro em negativo seguindo os passos do artista. Alguns anos mais tarde, a ideia de rastro reapareceria na obra Fairy Tales, no trabalho The Leak (São Paulo, 1995) e na famosa ação Paradoja de la praxis 1 (1994), em que Alÿs empurrou um enorme bloco de gelo pelas ruas da Cidade do México durante mais de nove horas, até seu completo derretimento.

Através de seus passeios - como o artista os chama - Alÿs formula enunciações e narrativas, tanto no sentido literal quanto metafórico. Suas fábulas urbanas tecem histórias pelas ruas por onde passa, territorializando-as com seus pés. O registro de suas ações pode ser uma espécie de pegada invisível, um mito que se cria e se alastra pelas cidades que percorre. Torna-se ele mesmo um personagem, inventando para si uma identidade, apropriando-se de cada cidade a seu modo, minando algumas máximas como a ideia de que tempo é dinheiro. Em vez de esculturas materiais, produz situações escultóricas, molda os tempos e espaços comuns com seus movimentos de territorizalização, desterritorialização e reterritorizalização.

Outras táticas de reconhecimento e de agenciamento territorial são elaboradas pelo artista em trabalhos como Narcoturism, Doppelgänger, Railings e La Résidence - todos desenvolvidos em cidades estrangeiras. Em cada um, Alÿs propôs caminhadas em que os sentidos empregados foram subvertidos, afogados ou exaltados, desanestesiando visão, tato, olfato e intelecto, abrindo-se para o não saber e mesmo para o não ser. Em Doppelgänger, quando o artista se coloca no papel de sombra ou de sósia de outrem a quem passa a seguir, a ideia de ser estrangeiro atinge novos limites, como a de ser estrangeiro à sua própria vontade ou identidade. Em Narcoturism, ao usar psicotrópicos variados ao longo de 7 dias consecutivos, Alÿs abafa a censura da consciência e mesmo da legislação local para deambular por Copenhague drogado ou alcoolizado. O som ultrapassa as barreiras impostas ao tato pelas cercas londrinas em Railings e a visão é bloqueada enquanto o tato e a audição são testados em La Résidence.

Realizada em 2002, a quixotesca e colossal ação Cuando la fe mueve montañas foi um marco na carreira de Alÿs. Nela, o artista e seus colaboradores convidaram 
500 voluntários para deslocar alguns centímetros de uma montanha de areia com o esforço de seus corpos e pás, ao longo de um dia. A ação foi desenvolvida em um pueblo pobre e periférico de Lima, nas margens da megalópole. A partir dali, Alÿs diz ter percebido o potencial político de alguns projetos artísticos e sua visão, até então atrelada à ideia de que às vezes fazer algo não leva a nada, passou a explorar a possibilidade de algo se transformar em algo - como no trabalho The Green Line, que recebeu como subtítulo às vezes fazer algo poético pode se tornar político e às vezes fazer algo político pode se tornar poético. Neste projeto, datado de 2004, Alÿs realizou uma nova versão de The Leak, em que novamente carregou uma lata de tinta furada ao longo de sua caminhada. Desta vez, porém, sua deriva obedeceu a uma linha previamente traçada no mapa: a chamada Green Line, que desde 1948 divide Jerusalém entre Israel e Palestina.

O tema das fronteiras reaparece em inúmeros trabalhos de Alÿs, mas destacamos neste artigo duas ações recentes, em que as fábulas inventadas pelo artista vêm carregadas de simbologias e de subjetividade política:

\section{Puente/Bridge, 2006}

Imagine uma negociação proposta por um desconhecido a diferentes grupos de barqueiros, pescadores e velejadores para criarem, a partir do enfileiramento de seus barcos, casco a casco, uma fila o mais longa possível, mar adentro, afim de chegar na linha onde céu e oceano se confundem, onde o horizonte se divide em dois tons de azul. Imagine recrutar centenas de voluntários para essa ação artística em dois países separados por alguns quilômetros de água, no intuito secreto de formarem, a partir da união de seus barcos, uma ponte. Imagine ainda que essa intenção não é revelada a nenhum dos navegadores, de tal modo que ignoram a presença da ação na fronteira oposta mas, mesmo assim, se alinham rumo ao horizonte. Agora imagine que esses dois países são Cuba e Estados Unidos.

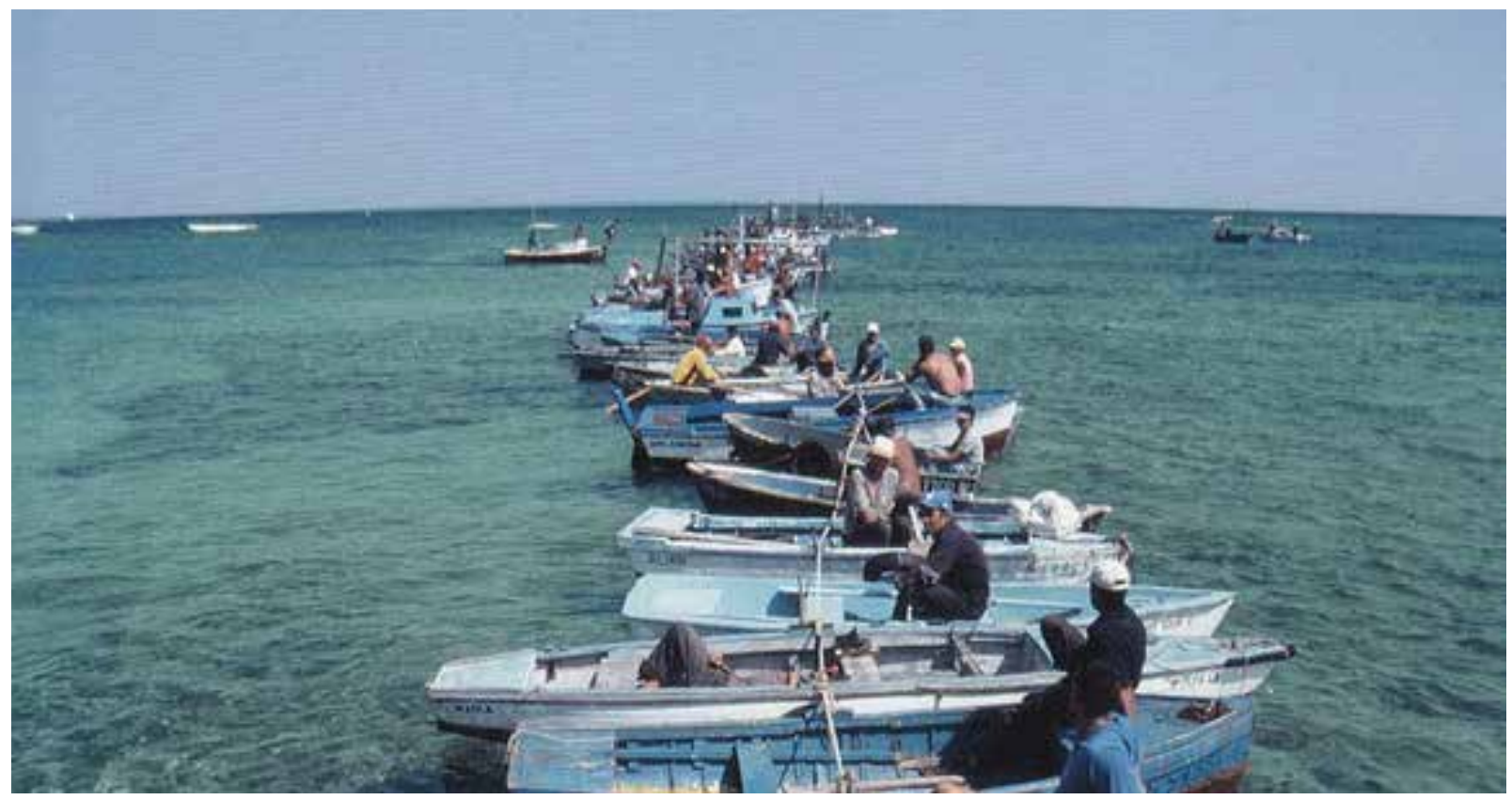

Francis Alÿs em colaboração com Tayana Pimentel e Cuauhtémoc Medina. Puente, 2006. Documentação fotográfica de um evento. Fonte: FERGUSON; FISHER; MEDINA, 2007, p. 107. 


\section{Don't cross the bridge before you get to the river, 2008}

Era o mês de agosto, auge do verão, e o mar estava convidativo. Em meio às ondas, dezenas de crianças formavam uma fila indiana, entrando na água uma atrás da outra, todas com seu brinquedo em mãos. Reparando bem, os brinquedos eram barcos, mas no lugar de um casco havia um chinelo, desses de borracha que boiam. Cada vez iam mais fundo e outros surgiam em seu lugar. Parecia que brotavam da areia com seus barcos-sapatos, um mais colorido que o outro. Tinham vela e leme para flutuarem melhor, caso ficassem à deriva: engenhoso, dessas coisas que os pequenos inventam. Dava a impressão de ser uma marina imaginária, uma regata, talvez até uma gincana. De repente só se via o barquinho, a criança sumia na onda, depois reaparecia. Até onde chegariam? Daquela margem quase se via podia ver o Marrocos, do outro lado, menos de 15 quilômetros de distância de uma borda à outra... Ficaram assim por muito tempo, entrando e nadando pro fundo. Não dá pra saber se conseguiram o que queriam, mas olhando daqui pareciam contentes.

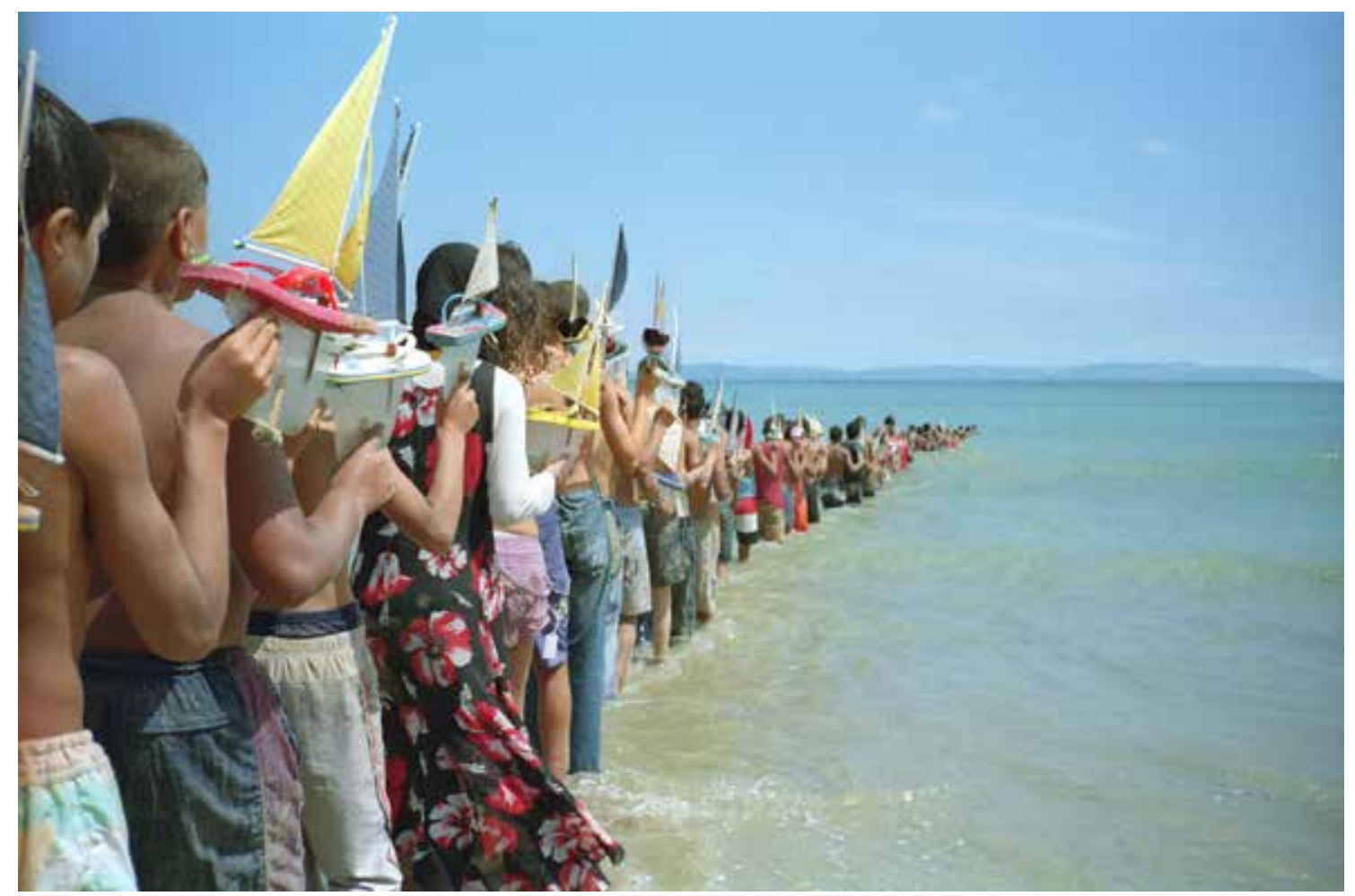

Francis Alÿs em colaboração com Rafael Ortega, Julien Devaux, Felix Blume, Ivan Boccara, Abbas Benhim, Fundación Montenmedio Arte e as crianças de Tangier e Tarifa. Don't cross the bridge before you get to the river, 2008. Documentação fotográfica de uma ação. Fonte: <http:// www.japantimes.co.jp/culture/2013/05/09/arts/ replaying-peoples-actions-with-a-twist/>

As duas ações, Puente/Bridge e Don't cross the bridge before you get to the river, distam dois anos entre si e soam como duas imagens criadas a partir de um roteiro comum. Por mais distintas que sejam suas posições geográficas no globo, a situação de fronteira - de borda com vista para o mar - conecta as quatro cidades envolvidas nos dois projetos: Havana (Cuba), Key West (EUA), Tarifa (Espanha) e Tangier (Marrocos). Ambas ações são propostas por Alÿs e alguns de seus colaboradores à população local, sejam pescadores ou crianças em veraneio. É um convite, novamente incitando à participação voluntária. 
Alÿs utiliza os canais de fluxo e de trânsito que estão ao alcance da população para questionar as linhas arbitrárias e muitas vezes invisíveis, nem por isso menos difíceis de cruzar, entre fronteiras. Propõe elos entre limites impostos, evidenciando o absurdo peso que carregam apenas alguns poucos quilômetros de água a separar essas margens. $O$ artista expande o conceito de espaço público para além das ruas e praças urbanas, alcançando as praias e as águas de domínio público, o mar. Se Cuando la fe mueve montañas já acenava para essa expansão rumo aos limites urbanos, nos dois últimos projetos Alÿs vai mais fundo.

Certeau nos fala de direito ao acesso, ao heterogêneo, à apropriação. Alÿs nos propõe maneiras de atualizar esse discurso através de ações poéticas. A ponte a ser construída coletivamente representa uma união tida por impossível entre dois mundos de acentuadas diferenças culturais, políticas e econômicas. Alÿs incita a população local a não se resignar, a questionar as linhas que separam seus países ou seus continentes, que limitam seu direito de acesso e de apropriação. Mas o faz de forma sutil, poética, sem ser panfletário. Em Don't cross the bridge, a documentação da ação não nos revela o início ou o fim do processo, apenas um contínuo meio, em progresso. No vídeo que registra a ação, sequer descobrimos até onde as crianças foram ou se chegaram a se encontrar no espaço entre as duas margens. Resta a dúvida.

Quando sai dos centros e caminha rumo à periferia, às bordas da cidade ou às margens de uma nação, Alÿs realiza na prática o que Certeau, Rancière, Deleuze e Guattari esboçam em teoria. Não se contenta em registrar ou problematizar o esvaziamento dos tradicionais núcleos da pólis, a gentrificação, a periferização ou o banimento de parte da população dos centros de poder mundiais. Busca também ele, em sua trajetória poética, realizar o movimento contrário: ao invés de permanecer no centro reclamando a presença daqueles que foram excluídos vai ao seu encontro, incentiva a sua participação criando novos espaços comuns, novos centros e possibilidades de inclusão para além daqueles lugares, fazeres e discursos estabelecidos.

Toda proposta parte do dissenso. No vídeo que documenta Puente, logo no enunciado é declarada a assimetria entre a quantidade de barcos participando da ação no lado norte-americano (32), da mais de uma centena de embarcações cubanas. Não existem acordos e a negociação de onde parte o artista evidencia essa necessidade política em lidar com sujeitos plurais, não apenas em seus objetivos, mas em suas visões, identidades e papéis no projeto proposto e no contexto existente. Alÿs não somente suspende a realidade, mas é como se estivesse posicionado num momento anterior, onde e quando o real ainda é possível, onde tudo está a ponto de ser. Segundo o artista "não se mudou nada, mas se introduziu por algumas horas a possibilidade de mudança, para além do absurdo e futilidade do ato." (ALŸS; MEDINA, 2005, p. 105).

Rancière escreve que o conceito de vanguarda artística só faz sentido quando temos a "invenção de formas sensíveis e dos limites materiais de uma vida por vir." (2009, p. 43). Criar pontes é o que fazem nossos pensamentos, gerando novas sinapses, associações e significados possíveis para conceitos já existentes e para aqueles que ainda virão a ser. O mesmo procedimento é incentivado por Alÿs, buscando novas formas de pensabilidade sobre uma situação já não mais questionada em seus fundamentos. O artista cria uma ficção. De acordo com Rancière "o real precisa ser ficcionado para ser pensado [...]" (2009, p. 58) o que não corresponde a dizer, como 
nos alerta o autor, que tudo é ficção, outrossim que no atual momento, na era da estética "escrever a história e escrever histórias pertencem a um mesmo regime de verdade." (RANCIĖRE, 2009, p. 58).

Embora ficcional, um enunciado faz efeito no real, alterando as sensibilidades $\mathrm{e}$ possibilidades de absorção, de comunicação ou de criação de novas situações, redesenhando o mapa do sensível, desnaturalizando postulados. Desnaturalizar a certeza de que Cuba e EUA ou de que África e Europa são realidades completamente distintas, inconfundíveis e apartadas, é um provocação que Alÿs lança com suas ações. Como o filósofo insiste: a arte pode ser um elemento de "transformação do pensamento em experiência sensível da comunidade." (RANCIĖRE, 2009, p. 67). Não se trata de uma simples aceitação dos clichês e estereótipos sobre as diferenças já tão consolidados em nossos discursos, são novas possibilidades de subjetivação e de desnaturalização do que é partilhado entre essas comunidades.

Ao propor ações processuais em que o percurso torna-se mais importante do que o ponto de partida ou o de chegada, Alÿs nos remete a um espaço entre. O que existe entre essas comunidades, esses países? $O$ artista estimula a criação de duas linhas, mas o que interessa é a maneira de realizar este movimento. Deleuze e Guattari defendem que "o que distingue a viagem não é a qualidade objetiva dos lugares, nem a quantidade mensurável do movimento - nem algo que estaria unicamente no espírito - mas o modo de espacialização, a maneira de estar no espaço, de ser no espaço". (1997, v. 5, p. 190).

Certeau faz uma diferenciação importante ao conceituar o termo espaço. Enquanto um lugar seria "uma configuração instantânea de posições" (CERTEAU, 1994, p. 201) e indicaria estabilidade, fixidez, relações de ordem referenciadas, a ideia de espaço implicaria fluxos, cruzamentos e estaria atrelada à de mobilidade. Se adotamos, neste artigo, o conceito de espaço para analisar a poética Alÿs é justamente por entendê-la como deslocamento, como uma série de práticas que se instauram gerando movimentos sem se submeter às linhas estratégicas que criam os lugares e os mantêm estáveis. 
Quando se apropria de um mapa e nele insere figuras que simbolizam movimento, o artista gera territorializações, desterritorializações e reterritorializações. Não apenas as representações gráficas de Puente e Don't cross the bridge apontam para esse gesto, mas as ações desenvolvidas nessas margens parecem ecoar o significado de espaço para Certeau ou aquilo que define a pólis: local de projeção da sociedade ou mesmo local do teatro espontâneo. É curioso resgatar, aliás, alguns dados acerca de mapas e da própria denominação original de atlas que, como comenta Certeau (1994), atendia pelo nome de teatro.

Somente após a intervenção da geometria (inicialmente euclidiana e atualmente descritiva) é que o conjunto de mapas e a própria ideia de mapa foram paulatinamente perdendo seu vínculo com as atuações, com a vida social que neles tomava forma, deixando de ser teatro para se tornar atlas. Tornaram-se distantes, abstratos, com pretensões totalizantes. Vale recordar que o próprio nome atlas foi cunhado a partir de Mercator $^{2}$, renomado cartógrafo belga responsável pela representação mais usual do globo terrestre em duas dimensões até hoje. Mercator desenvolveu em sua técnica cartográfica aquela tradicional imagem onde a Europa fica no centro do planeta (e do mapa) e suas dimensões são exageradas em relação a seu tamanho natural, enquanto a África é reduzida, por exemplo.

Essa cientifização falsamente neutra acarreta um afastamento entre a cidade das representações e aquela das apropriações. A primeira passa a ser descrita através preferencialmente de mapas, como um quadro estático; enquanto a segunda necessariamente envolve ações, percursos. Na primeira algo está à direita, ao norte ou a três quilômetros, na segunda se dobra à direita, se caminha rumo ao norte, se percorrem três quilômetros. Ao inserir a possibilidade de pontes que dependem da existência e do movimento das pessoas para existir, Alÿs funde essas duas formas de aproximação, recria a conexão e retoma, a partir de um mapa, o teatro que nele toma parte.

Quando elabora um roteiro em que a linha que constitui a ponte se desfaz, propositalmente, ao final da ação, Alÿs declara que não pretende construir uma ponte real, torná-la um lugar na paisagem ou um legado a ser patrimonializado. Converte, outrossim, o lugar que caracteriza a fronteira em um espaço, o cria a partir de seu enunciado poético e da ação que o sucede. Certeau disserta que ali onde os relatos deixam de existir há uma perda de espaço, uma tendência à museificação das cidades, privadas de suas práticas narrativas. É um fenômeno próximo à cristalização dos tradicionais centros urbanos transformados em centros históricos para turistas e esvaziados de sua vida social e política. Alÿs presentifica os espaços através de seus deslocamentos e narrativas pedestres, rasurando as bordas ou tornando-as um novo espaço entre. "No relato, a fronteira funciona como um terceiro. Ela é um 'entre dois' - 'um espaço entre dois'." (CERTEAU, 1994, p. 213).

O enunciado que acompanha o vídeo em Don't cross the bridge before you get to the river revela que a intenção do artista não era a de conectar Espanha e Marrocos através de engenharia náutica - o que não seria difícil, visto que distam apenas treze quilômetros no Estreito de Gibraltar. Alÿs convida crianças para levarem seus barcos de chinelo, como uma ação ritualística, mística se quisermos. Ao mudar a escala de bar-

2 Disponível em: <http://www.historiadacartografia.com.br/projecao.html>. Acesso em: 8 fev. 2017. 
cos de verdade para aqueles de brinquedo, faz "crescer" as crianças, como se fossem gigantes, como os monstros mitológicos que habitam as águas mitológicas. Através de sua ação, realiza o que outrora os romanos faziam em rituais de fundação, em seus fetiales, com marchas que ocorriam primeiro dentro do próprio território, depois na fronteira e, finalmente, no território estrangeiro. "A ação ritual se efetua antes de toda ação civil ou militar porque se destina a criar o campo necessário para as atividades políticas ou bélicas." (CERTEAU, 1994, p. 210).

Seria esse o primeiro papel do relato para Certeau: abrir um teatro que legitimaria as ações efetivas posteriores. Muito similar à defesa de Rancière quanto ao papel da ficção em nossa era estética, gerando efeitos no real. E o aspecto ficcional da ação que surge a partir de um roteiro, sendo lançada no imaginário, mas que não se conclui, é reiterado pelas formas de visibilidade que Alÿs e seus colaboradores proporcionam nesses dois trabalhos. Não sabemos se as linhas se tocaram no horizonte - restam a curiosidade, os rumores, o mito, a fábula. No projeto realizado no estreito de Gibraltar, a questão surge como pergunta no início do filme que promete, mas não conta o fim. Conforme as crianças avançam, a câmera mergulha, perde-se na água e o movimento parece repetir-se a cada vez que se aproxima de uma conclusão. Segundo o artista (2010), trata-se de "um presente a ser continuado."

\section{REVERBERAÇÕES}

Alÿs deixa seu universo se contaminar pelo potencial político que, ao longo de sua trajetória, se torna mais evidente e produz um esgarçamento dos limites de sua prática artística. Observação, conhecimento, reconhecimento, registro; intervenção solitária, com colaboradores e com voluntários: não é um caminho sem volta, mas denota novos horizontes dos quais partir e para os quais retornar. $O$ artista declara ainda que 0 que lhe interessa é esse meio, esse presente a ser continuado onde ele mesmo se situa, entre a apologia e a crítica à forma como latino-americanos resistem ao progresso, por exemplo. No processo de modernização nunca alcançada, Alÿs parece ter encontrado uma metáfora para sua própria maneira de produzir. É seu modo de estar no espaço, é nessa cadência de fatos sem começo nem fim que encontra suas possibilidades de criação. É nesse momento do não saber e do não pensamento, como diria Rancière, entre fazer e desfazer, entre avançar e recuar, que identifica pausas significativas, abrindo brechas para o novo surgir, para iminências emergirem.

A contribuição de Alÿs nesse panorama pode ser sua maneira nômade de habitar os espaços comuns, colocando-se sempre no limiar: entre observação e participação, entre local e estrangeiro, entre trabalho e lazer, entre autor e espectador, entre central e periférico. $O$ artista espacializa tanto a cidade quanto suas margens, desertos e mares. Certeau indica que "onde o mapa demarca, o relato faz uma travessia [...] instaura uma caminhada (guia) e passa através ('transgride'). O espaço de operações que ele pisa é [...] topológico, relativo às deformações de figuras e não tópico (definidor de lugares)." (1994, p. 215). Quando escreve sobre delinquências e coloca um ponto de interrogação ao lado da palavra, Certeau (1994) nos interroga, pois sua figura do delinquente seria a daquele ou daquilo que vive nos interstícios, sempre em movimentos contrários ao da estratégia, desmanchando e deslocando suas barreiras, gerando espaços topológicos. 
Entre o aprisionamento em padrões e alinhamentos disciplinares (caracterizado por agendas funcionais, espaços públicos programáticos, cidades claustrofóbicas e burocráticas, barreiras nacionais e xenofobia) e o desvio na ilegalidade com sua errância perpétua, existiria uma delinquência possível? Como se daria uma narrativa delinquente compatível com esse movimento de estar ao mesmo tempo inserido e fora da sociedade e de suas regras, da cidade e de seu planejamento? Certeau acredita que o corpo em movimento seja o primeiro passo dessa narrativa. Alÿs, em sua poética urbana, reforça essa intuição de Certeau, compartilhada por Deleuze e Guattari em sua descrição sobre o espírito libertador, troglodita e nômade.

Ao criar linhas com o fio de seu suéter, com rastros de gelo ou com voluntários, o artista nos recorda que os traçados político-geográficos são arbitrários em sua maioria e que será o uso ao longo do tempo a reforçar ou borrar essas linhas. Como podemos, em nossas práticas urbanas, cancelar ou ignorar a existência de linhas que visam controlar nossa circulação e nosso acesso? Quando ignora, transpõe ou atravessa limites, Alÿs não suprime as fronteiras, mas desfataliza sua existência, questiona sua perenidade e duração, permite uma atitude menos reverente frente aos limites impostos - na arte, nos limites do urbano e nas fronteiras nacionais. Talvez esse seja um caminho.

Se fecho os olhos, deixo de enxergar as barreiras visuais colocados na paisagem, subverto os sentidos em que operam as fronteiras - talvez essa seja outra possibilidade. Se todos deixarmos de ver ou de acreditar nos limites, eles seguirão existindo? Quanto há de bloqueio criado, de construções culturais que nos fazem acreditar que não podemos avançar? Quão absurdas podem parecer as barreiras que cristalizam protocolos sociais em gestos contidos, em classes definidas, em gêneros estanques, quando esses limites deixam de fazer sentido para cada um de nós? Como a arte pode afetar essa percepção individual, criando valores subjetivos? E como ela pode ainda ecoar, contaminando uma comunidade inteira?

Desde pequenos somos ensinados a não falar com estranhos. Que estranhamentos evitamos em nossas rotinas urbanas? Interessa aqui extrapolar a visão aplicada às artes ou ao urbanismo e entendê-la como uma tomada de posição mais abrangente, uma maneira de criar esses espaços de iminência, de caminhar tanto sobre as fronteiras divisórias a ponto de gastá-las, de apagá-las. Ou, no mínimo, de espessá-las e torná-las um novo espaço. Caminhar e deixar-se ficar nas bordas seria uma opção para não reforçar clichês, para desafiar os acordos, gerar atritos, para sairmos do terreno seguro do familiar. Por que não nos colocamos nesse papel de estrangeiros em nosso dia a dia? Que exercícios seriam necessários para nos desanestesiarmos, para possibilitarmos estar de novo à flor da pele, receptivos ao estranhamento? O quanto nos custa deixar morrer nossas certezas e com isso liberarmos espaço para a criação do novo? Desterritorializar para então reterritorializar nossa própria vida.

Assim como na poética de Alÿs, vale entender o que é preciso deixar ficar em nossas dinâmicas, o que vale a pena ser mantido e o que tem mais significado desfazer. Alÿs nos propõe um questionamento sobre a necessidade de criarmos produtos concretos e duradouros. Ao falar de processo, desloca a importância para o enquanto, para os instantes de coincidência. É um modo não patrimonialista de pensamento. No tipo de projeto desenvolvido por Alÿs e que aqui defendemos, a relevância migra 
do produto final a ser eternizado para a valorização dos fazeres dinâmicos - estejam eles em latência ou em atualização.

Alÿs opta, desde o início de sua trajetória, por projetos que se tornem fábulas a serem espalhadas preferencialmente por meio de narrativas orais. Sabemos que na composição da História como disciplina, os registros orais ficaram, até o final do século XX, relegados a segundo plano, a estórias. Ao escolher uma história alternativa - a da oralidade - Alÿs opta por uma história feita de carne e não de esqueletos. Boatos e rumores que passam de boca em boca compõem e refletem narrativas feitas de duração, de presentes que não museificam nem cristalizam, mas sim contextualizam e atualizam.

Avançando por esse caminho, pensamos na decisão científica de transformar a escrita num marco histórico de suma importância. Certamente não é uma decisão neutra - ela vem carregada de uma ideologia. Podemos entender a escolha de Alÿs pelo viés da tática certauniana e, ainda nessa linha, debater o quanto há de transgressor ou, no mínimo, de crítico e de dissensual, ao adotarmos essa postura que privilegia uma história não baseada no registro da palavra escrita. Vale lembrar ainda que muitas das civilizações indígenas pré-colombianas não tinham sistemas como o da escrita e do alfabeto. A visão de sociedades menos civilizadas e desenvolvidas cerca a história latino-americana contada a partir de uma perspectiva eurocêntrica, que rapidamente transforma, por exemplo, povos não alfabetizados em povos analfabetos, primitivos.

Ao adotar a fábula como mecânica de contaminação de seu trabalho, Alÿs quebra, por diferentes motivos, essa lógica colonialista e possibilita uma partilha comum. O primeiro motivo é a constatação de que todas as civilizações são dotadas de fala. Não há, nesse sentido, nenhum filtro criado - como o alfabeta ou escrita - para se ter acesso à experiência. A única premissa dessa partilha é a capacidade comum da fala e da escuta. O segundo motivo parte deste ponto: para que uma narrativa oral circule o compartilhamento se faz necessário. Ao contrário da escrita, que pode ser individual, a criação de histórias que se espalham por rumores é iminentemente coletiva e processual, sendo ativada toda vez em que é contada. Finalmente, ao passo que a escrita pressupõe ainda uma superfície sob a qual plasmar o texto (pedra, cera, madeira, pergaminhos, papéis, telas...) o som se propaga através de meios que estão ao nosso redor o tempo todo, como o ar ou a água.

As ondas sonoras que possibilitam a transmissão das fábulas podem atingir um longo alcance e têm a capacidade de se transformar a partir dos obstáculos encontrados pelo caminho. Ondas sonoras, além disso, não transportam matéria, somente energia. Um trabalho artístico baseado em ações que não carregam matéria - que porém provocam deslocamento de energia possibilitando novas vibrações - nos revela uma potência transgressora significativa. Trata-se de perceber que toda matéria necessária para gerar transformações já está posta na realidade, precisando apenas ser provocada. Essa percepção pode ser um primeiro passo para a emancipação social sobre a qual Rancière escreve em $O$ espectador emancipado (2010), coadunando para uma postura não colonialista de produção histórica que possibilite uma nova partilha comum.

Nas palavras de Deleuze, esses trabalhos artísticos têm a potência de "suscitar acontecimentos, mesmo pequenos, que escapem ao controle, ou engendrar novos 
espaços-tempos, mesmo de superfície ou volume reduzido." (1992, p. 222). Alÿs gera perturbações a partir do que encontra em seus deslocamentos, nas situações presentes nas cidades por onde passa, suscitando acontecimentos em diferentes escalas, que podem ser lidos como fábulas. Segundo o artista, sua trajetória é uma narrativa única, que parte da invenção de linguagens na qual cada ação é um trecho que ajuda na composição da cidade que está mapeado e inventando continuamente. Criar ficções para pensar o real, como afirma Rancière: a possibilidade do artista fundar espaços, ressignificar cenários e ações que neles se projetam. Individual ou coletivamente, Alÿs gera situações escultóricas que moldam as relações entre diferentes agentes. São intervenções que alteram nossa percepção e atitude frente a uma paisagem, aos limites impostos, às agendas contemporâneas, à burocracia nacional, ao desperdício, às comunidades tantas vezes chamadas de periféricas.

A partir de diferentes pesos e recursos, o artista elabora narrativas com alto potencial simbólico, capazes de nos fazer imaginar. São táticas para pensar utopicamente, desenhar mentalmente histórias, entrever possibilidades a partir de plataformas postas no aqui e agora, como as cidades com seus espaços e tempos comuns. A acepção de fábula requer um olhar mais detido para entendermos de que forma seus trabalhos podem constituí-las. Quando faz apontamentos críticos de forma indireta, buscando recursos alegóricos, Alÿs torna possível uma aproximação inaugural a um determinado tema. São como fagulhas que podem acender nossa imaginação, gerar curiosidade e surpresa. Assim as críticas presentes em seus projetos e seu modo de encarar a realidade encontram maior receptividade, evitando censuras tanto oficiais quanto particulares. Dito de outra forma, num mundo estriado ao extremo, saturado de imagens e informações que visam reiterar discursos hegemônicos, as pequenas inserções imateriais de Alÿs nos permitem uma leitura menos protegida e menos carregada de certezas frente a suas ações e registros.

Trata-se de uma produção menos capturável pelos sistemas de controle - cada vez mais disseminados em nossas relações com o mundo. A partir de enunciados curtos, desprovidos de moral declarada, ou por meio de desenhos simples - quase infantis -, Alÿs foge dos canais de comunicação padronizados e de bloqueios preparados pela estratégia, mas também daqueles individuais, com seus preconceitos tácitos. É como se o artista resgatasse a nossa capacidade de aproximação de imagens e mensagens de maneira mais porosa. Com leveza, aborda assuntos impregnados de lugares comuns e consensos forjados, como os dogmas do progresso, os processos de gentrificação urbana, a periferização e desurbanização das cidades atuais, bem como situações de conflito entre barreiras continentais. $O$ artista recorre a um imaginário lúdico, fugindo do vocabulário usual da mídia.

A partir de uma produção de experiências estéticas livres de significados decalcados, os projetos de Alÿs desterritorializam as imagens e vocabulários presentes numa dada situação e, assim, desanestesiam nossa percepção, criando pontes. Estamos diante de uma possível exploração do recurso da fábula, com seus personagens animais, que despersonificam as situações, quitam os nomes, nos permitem encarar apenas o que existe por trás do véu de classificações prévias. É como se Alÿs conseguisse acessar um potencial crítico e subjetivo ao desviar dos simulacros e da gratuidade de imagens e discursos prontos, normativos. Suas ações retiram os conceitos 
da inércia, extraindo situações de uma banalidade e de uma violência forjadas sobre o consenso.

Os trabalhos artísticos tomam emprestado da literatura sua qualidade de adaptação. Relatos orais tanto podem intensificar e reiterar uma história quanto permitir que cada parte se acomode em novos contextos e seja atualizada a cada nova situação que se apresenta. Assim as fábulas se moldam a cada meio onde são contadas, como nômades. A visão não dicotômica dos conceitos aportada por Deleuze e Guattari coincide com essa possibilidade criada por trabalhos poéticos-políticos como os de Alÿs, que são um e outro, ou que passam de um para o outro o tempo todo, em processo não determináveis e não estáveis. Em alguns casos, o ingrediente inventivo das fábulas pode ainda necessitar que novas palavras sejam criadas, que novas linguagens surjam e que espaços venham a ser.

Quando Alÿs inventa novas ações, inaugura situações para as quais talvez não tenhamos nomes ainda. De maneira similar às danças e aos rituais romanos descritos por Certeau (os fetiales), essas práticas poéticas criam uma nova possibilidade de tempo-espaço para que, a seguir, ele possa vir a ser territorializado. Podemos identificar esse busca na maneira como o artista se porta como alguém que não se satisfaz nem se cansa. Cada dia é uma nova jornada, uma nova estreia de possibilidades impulsionada pelo que a descoberta de novos espaços comuns tem a the oferecer. As derivas de Alÿs são tudo menos comodismo e inércia. Cada situação porta consigo uma nova possibilidade de identidade para o artista, que segue seus deslocamentos urbanos buscando seu próprio, se reencontrando na próxima cidade e em outro alguém, como em Doppelgänger.

Não se trata, portanto, de explorar tesouros escondidos e de fuçar no passado reiterado, mas sim de inaugurar novas fábulas, cidades e identidades através de práticas feitas de devir, de novos regressos, de se tornar. Aqui vale entender como ações poéticas, que agem no nível do sensível, criam valores subjetivos que podem impregnar não somente os indivíduos, particularmente, mas uma comunidade, um contexto urbano. Como é possível haver essa tradução ou contaminação, às vezes de forma simultânea, entre reverberações na escala tanto do corpo humano quanto da cidade? Partindo do que Certeau chama de microrresistências e que Deleuze e Guattari identificariam com as micropolíticas, avançamos rumo à cidade e vice-versa, num movimento de afetações e perturbações em que cada escala reage de forma distinta às provocações lançadas.

A cidade e o ambiente urbano representam a tentativa mais coerente e de modo geral mais bem sucedida, de refazer o mundo em que vive de maneira mais compatível com o que deseja seu coração. Mas se é o mundo que o homem criou, a cidade é o mundo no qual ele está doravante condenado a viver. Por conseguinte, de forma indireta, sem nenhum sentido claro do caráter de sua tarefa, ao fazer a cidade, o homem refaz a si mesmo. (PARK apud HARVEY, 2004, p. 210).

Seria talvez essa a força motriz de Alÿs: criar situações e esculturas sociais em que indivíduo e cidade estejam sendo moldados simultaneamente. Quando nos permitimos ser heterogêneos, mutáveis, quando percebemos que as transformações do mundo nos afetam em agenciamentos dinâmicos e constantes, damos um primeiro 
passo para esse entendimento de como nossos espaços e fazeres urbanos podem vir a ser.

Se aceitamos a alteridade, as mudanças e a necessidades de atualização e contextualização como os nômades, por exemplo, caminhamos rumo à possibilidade de transformação política de nossos espaços comuns, sejam eles de escala individual ou coletiva. A manutenção "harmoniosa" de cada classe em seu lugar e de cada um em seu papel seria o que Rancière chama de partilha policial do sensível: uma noção forjada na ideia de inferioridade dos trabalhadores que deveriam ser mantidos em suas ocupações, espaços e tempos condizentes com suas "capacidades de sentir, de dizer e de fazer que convém a essas atividades." (RANCIÈRE, 2010, p. 64).

Quando Alÿs desarranja um determinado meio, provocando reverberações que deslocam energia com suas ações, desestabiliza a ordem imposta e permite que os papéis sejam desacomodados. Ao convidar voluntários para suas ações e partilhá- las através de fábulas e de linguagens comuns, Alÿs não pretende "levar cultura às massas". O artista parte do pressuposto de que todos já dispõem das capacidades necessárias para participar das experiências estéticas propostas, bastando, para isso, que haja provocação, como nas ondas sonoras. As ações de Alÿs transportam apenas energia, fazendo reverberar elementos que já estão postos numa dada situação, num contexto social urbano. $O$ artista acredita na potência emancipadora e, portanto, política dessas ações. Mesmo sem estar seguro a respeito de sua capacidade de transformação real ou imediata, segue provocando, com seus gestos micropolíticos, pequenas perturbações na partilha do visível, fazível e pensável. Citando novamente sua frase "[...] não se mudou nada, mas se introduziu por algumas horas a possibilidade de mudança." (ALŸS; MEDINA, 2005, p. 105).

\section{REFERÊNCIAS BIBLIOGRÁFICAS}

ALŸS, F. Numa dada situação/In a given situation. São Paulo: Cosac Naify, 2010.

ALŸS, F.(et al.). Francis Alÿs: Seven Walks, London 2004-5. Londres: Artangel, 2005.

ALŸS, F. In: FERGUSON, R.; FISHER, J.; MEDINA, C. Francis Alÿs. Londres: Phaidon, 2007.

CALVINO, I. As cidades invisíveis. 2. ed. São Paulo: Companhia das Letras, 2003.

CANCLINI, N. G. A sociedade sem relato: Antropologia e Estética da Iminência. São Paulo: Edusp, 2012.

CERTEAU, M. A invenção do cotidiano: Artes de fazer. Petrópolis: Vozes, 1994.

DELEUZE, G.; GUATTARI, F. O que é a filosofia? 3. ed. São Paulo: Editora 34, 1992.

Mil Platôs: Capitalismo e esquizofrenia. V. 5. São Paulo: Editora 34, 1997. 5 v.

DELEUZE, G.; PARNET, C. Diálogos. São Paulo: Escuta, 1998. 
FERGUSON, R.; FISHER, J.; MEDINA, C.; Francis Alÿs. Londres: Phaidon, 2007.

HARVEY, D. Espaços de Esperança. São Paulo: Loyola, 2004.

LAGNADO, L.; PEDROSA, A. (Org.). 27a Bienal de São Paulo: Como viver junto. São Paulo: Fundação Bienal, 2006.

RANCIĖRE, J. A partilha do sensível: estética e política. 2. ed. São Paulo: Editora 34, 2009.

O espectador emancipado. Lisboa: Orfeu Negro, 2010.

<http://www.francisalys.com/>. Acesso em: 8 jul. 2017. 